\title{
THE CRISIS OF NATIONALISM IN INDONESIA-MALAYSIA BODER: A DISCOURSE ANALYSIS OF THE NARRATIVE FILM OF 'TANAH SURGA...KATANYA'
}

\author{
I Nyoman Suaka, I Gede Bagus Wisnu Bayu Temaja \\ IKIP Saraswati, Bali, Indonesia \\ Jl. Pahlawan 2, Tabanan, Bali, Indonesia \\ Corresponding Author: imansuaka@yahoo.co.id
}

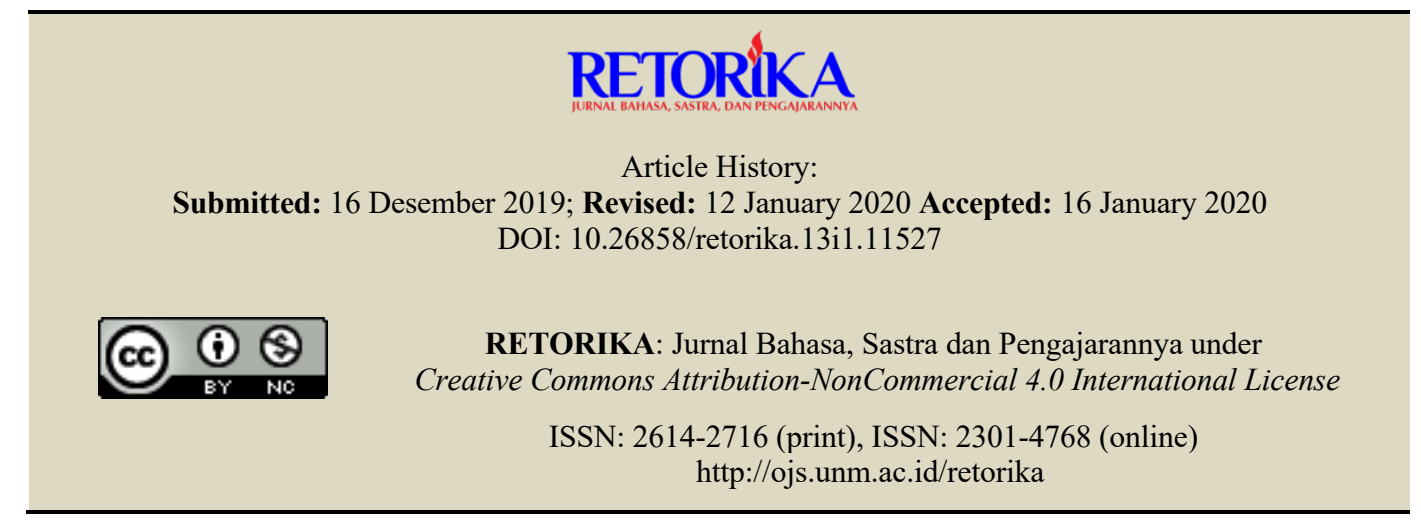

\begin{abstract}
This study aimed to identify the nationalism values in "Tanah Surga...Katanya" film. It is a qualitative descriptive study based on audiovisual of film. The results indicate that, in the border, the value of Indonesian nationalism is faded, such as lack of recognition of the Indonesia Rupiah, low appreciation on the national anthem, and looking down on the potential of the region. That condition is due to the government's lack of attention to education, health, transportation, communication, and economic facilities. But, on the other hand, the spirit of nationalism and nationality emerged, as well as sacrifice to defend the country.
\end{abstract}

Keywords: film, Indonesia-Malaysia border, nationalism

The Indonesian films which reveal the con-dition in the border region are relatively rare compared to the many problems on the border between Indonesia-Malaysia. In 2012, the scarcity was overcome by watching a film titled "Tanah Surga...Katanya" that was directed by Herwin Novianto, with the writer of the story, Danial Rifki. At the same year, the film successfully won five prestigious awards at the Indonesian Film Festival (FFI) which was held at the Venderbugh Fortress in Yogyakarta, Indonesia. The five awards were the best director, Herwin Novianto, the best male supporting actor, Fuad
Idris, the best original story writer, Danial Rifki, the best artistic order, Eszra Tampubolon, and the best musical arrangement, Theorsi Argeswara.

The film tries to discuss the form of nationnalism and nationality in the border area which turns out to harbor many conflicts. This conflict often appears in the world of reality, therefore it is fascinating to study from another perspective, which is a film to take a look at the relationship between Indonesia and Malaysia. The relation between of both country are often disrupted by political, legal, labor, and environ- 
mental (forest fire) problems, even though the two countries are allied nations that have many similarities culturally with a background of Malay culture.

This very intimate relationship of Malaysia-Indonesia culturally had also experienced tensi-on because Malaysia recognized Pendet dance, which is native to Bali, as their dance. But, in pop culture, Sartono (in Heryanto, 2012:1-3) noted that several Indonesian singers and musicians are warmly welcomed in Malaysia. This has happened several decades before the success of Indonesian artists such as Titiek Puspa, Lilis Suryani, duet Sandhora-Muchsin, Koes Ploes, Dloyds, Broery Marantika, Bob Tutupoly, Harvey Malaiholo, and Vina Panduwinata, performing in Malaysia. On the contrary, a Malaysian artist, Siti Nurhaliza, who is a favorite in Indonesia, has a big role in reducing the tensions that have hit two countries in the area boundary problem near Ambalat Island in 2005.

In the film of "Tanah Surga...Katanya" that which is part of pop culture, it is indeed not as severe as the conflict experienced by the two countries. But, it needs to be watched out because the people in the border area, especially in the Indonesian region, have a very low level of welfare compared to those in Malaysia. Economic conditions, infrastructure, education, and health are very concerning as often complained about in the news in print and electronic media. In addition, this film contains criticism, innuendo, and social protests at the same time to the government that cares less about development in the border region, so that they are far behind, isolated from other Indonesian people. By watching the film, the identification of the problems are and what is the story of the film? What problems do the characters experien-ce? What is the actualization of the values of nationalism and nationality in a film set in Borneo-Sarawak border?

Those problems were examined from the perspective of naratology discourse. A film is a text of discourse. The discourse of a film must contain a narrative and that is a story. There cannot even be a film if there is no story. The narrative element (storytelling) holds a strategic role because narration is the main element in a film. This narrative element gets the priority of the "Tanah Surga...Katanya" film because the committee gave an award to Danial Rifki who was named as the best original story writer in FFI 2012.

The reason for the selection of film as the object of analysis is in line with the opinion of Kracauer (in Said, 1991) that the film of a nation reflects the mentality of the nation more than reflected in other artistic media. This opinion is supported by two reasons, first, in the film, the director leads a group consisting of various artists and technicians. But in the work process, the director cannot avoid accommodating the contribution of various parties. Second, films are made for many people, thus taking into account the favor of as many people as possible. Thus, the film cannot be separated from the com-munity.

Looking at Kracauer's opinion, the story of the film which is classified into works of fiction cannot be separated from the actual facts in the world of reality. Film stories can be said to be the result of a combination of the world of facts and the world of fiction, as in literature. This is confirmed by Sobur $(2006: 129)$ who says that the signs of the film do something that is not much different from romance or novels. The film presents fictional texts that give rise to a (global fictitious) world that might exist. The problem of the tension between fiction and nonfiction that appears in literature basically also appears in the film. Thus the narrative theories in literature are very relevant to be used to study of film stories.

In humanity research, between films and literary works seems to be running out of balance. Said (in Ismail et al., 2004) states that many films are produced in this country, but there is so little talk about them, compared to research on Indonesian literature. According to Said, the film is clo-ser to the crowd. Therefore, it reflects more attitudes, dispositions, tendencies, obsessions, and dreams of many people. However, observers of the film regret that the film was left neglected by humanity researchers (Ismail et al., 2004: 131).

Kracauer's and Said's statements above, encourage writers to review "Tanah Surga... Kata-nya" film, directed by young director Herwin Novianto. In addition, the struggle of the figures representing the lower classes of society in this film is very interesting to study. The theme of this film is very distinctive compared to theme that mushroomed in Indonesian films such as 
romance, affair, ghosts, and luxury of sacrificing ethics, logic, and story aesthetics.

Research on Indonesian films is still limited in number compared to Indian or Chinese film studies. However, currently, film studies are starting to emerge in the form of theses and journals in line with the development of cultural studies. Cultural studies give great attention to the culture of media and popular culture such as films. At present Indonesian film studies, according to Paramadhita (2009), still face problems due to weak filing system and rare bibliography (see Power book Preface in Khrisna Sen's Cinema).

Research on Indonesian films which are now often referred to in Indonesian film studies has been carried out by Heider (1991), Said (1991), and Sen. Heider's book entitled "Indonesia Cinema: Indonesian Culture on Screen" was written based on his interest in Indonesian films. He conducted ethnographic research in West Sumatra about formula films such as melodrama, horror, and comedy. Heider tried to find cultural patterns and understand how national culture is reflected.

Said's research entitled "Shadows on the Silver Screen: A Social History of Indonesia Films" is a historical analysis of the Indonesian film industry from 1926 until the late 1970s. Said revealed the history of the conflict between commercialism and the idealism that underlies film making. This is based on the statements of critics and film makers about the disappearance of the original Indonesian image in the film.

Sen's study refers to Anderson's opinion about the New Order as a period of "state victory over the nation," which was published in a book entitled "Power of Attorney in State Cinema, Society and New Order cinema." This researcher argues that institutionalization in the form of professional organizations, film festivals and regulations that are strictly controlled by the state form and produce special characteristics called Indonesian films. Sen in his research showed that Indonesian cinema cannot be understood except by referring to the economic and political transformations brought by the New Order government under President Soeharto.

Those three literature reviews above give great attention to the issue of nationality, nationnalism, and national culture at the elite level. The issue in the New Order era has now revived with the emergence of "Tanah Surga...Katanya" film, about the phenomenon of lower class nationalism. In fact, the film is considered brave enough to criticize government policies that are less concerned with the people in the border region as a lower society. To study more about this film, the focus of the discussion will be on the element of the story (narration) of the film, not on other elements such as the artistic order, musical arrangement, acting abilities of the actor, or directing. Film is a cultural discourse that contains narration, so that the theory of naratology discourse will be used as a "knife" to dissect the "Tanah Surga...Katanya" film.

According to Marwoto (1995:151), discourse is a form of oral and written exposure which is a container for delivering information or thoughts intact, such as monologue, dialogue, and polylogue. A good discourse must have a harmonious relationship between the elements on a regular and coherent basis, hence it is communicative and contains a meaning. Piliang (2003:54) provides an understanding of discourse relating to social practice in everyday life. As a language area, discourse is expressed as certain manners in speech, writing, and thinking. A discourse is not only related to language, but more importantly discourse is directly related to the practice of language and social relations.

Naratalogy comes from the word narratio (Latin) which means story, words, stories, and saga. Therefore, naratology means the field of science that talks about narratives as story. Nevertheless, in the literature developed is the second element, namely storytelling. In telling the story contained discourse, which in this paper is considered identical, synonyms even have the same characteristics as the text. The difference is that, the discourse has more to do with linguistics and with broader cultural prob-lems such as social, political, economic, legal, and so on, while the text has more to do with literature.

According to Ratna (2004:28), naratology in particular, in relation to discourse analysis, is considered as the object of study in understandding aspects of contemporary culture. If it is agreed that all life activities are built on the basis of language, then the discourse is the only energy to move the activity. Discourse under-lines social roles because language basically precedes action not vice versa.

Related to narrative discourse analysis, Genette (1983:25-30) states that the narrative analysis can be divided into three analyzes, 
namely: (1) analysis of narrative statements in relation to serial events, both oral and written; (2) analysis of narrative content in relation to sequences or real events or fiction as discourse; and (3) narrative analysis in relation to events in the story. The three stages are very relevant to be used to study the story of a film.

Related to this, Luxemburg et al., (1989: 119-120) state that discourse structure or narrative text is all discourse or text whose contents are a series of events, which are divided into narrative fiction structures and nonfiction narrative structures. Narrative fictional structures such as romance, short stories, narrative poetry, fairy tales, films, fantastic and realistic stories, anecdotes, jokes, gossip and so on. Nonfiction narrative structures such as diaries, biographies, newsletters, reports, minutes, and so on.

In line with the above opinion which mentions film stories as fictional narratives, then this discussion will intersect with the study of literature. In literary study, the word fiction is limited to mentioning narrative fiction or story (Wellek and Warren, 1956:204) between film and literature have parallels. Therefore, many literary works in the form of novel and drama were adapted into film or soap opera. Even in the history of world cinema, especially Hollywood, almost 90 percent of film stories are taken from the adaptation of novel stories (Karkono, 2013). This condition is also occurred in Indonesia that many novel stories are promoted into films and soap operas.

Related to film stories, Ratna (2004:29) asserts, fictional narrative structure is a series of events which contain fictional elements such as characters, backgrounds, points of view, themes, language styles, and so on. Therefore, RemmonKenan (in Ratna, 2004:29) states, in this connection it does not include gossip, official testimony, newspaper reports, history books, autobigraphy, personal letters etc. because pragmatically the narrative is lacking display fictional quality. By saying that, a narrative is a series of events, then definitively in a work, there is more than one event.

Luxemburg et al., (1989:120) mentions three characteristics of narrative fiction, namely: the heterogeneity of the use of language as a result of the intervention of the primary narrator (storyteller) and secondary narrator (narrator); there are characteristics of fictionality, how a world is viewed (focalization) in the story; dan the existence of a fictional world structure, how a story is rearranged so that it becomes a plot.

According to Pujiharto (2012: 32-33), every work of fiction must present a story. The story consists of events. These events are not merely lined up, but have a causal relationship with each other. This is called the groove. In regards to events in the plot with simple language can be called, events are the transition from one state to another.

Besides events, there are episodes in the film flow. Episode is a collection of events arranged in such a way. Within it, there is a se-ries of events which contain an initial state, a change, often a complication, and a final state (Luxemburg et al., 1989:138). This opinion is different who equates episodes in fiction with scenes in drama. The scene is said to be part of the round in the play. Ordinary scenes are characterized by the transition from one state to another. Thus means, Stanton mentions episodes while Luxemburg refers to events. Generally, in the world of film, the term episodes are more like what will be mentioned in the discussion of this paper.

A research on nationalism in literature already conducted by Ismawati (2018). She focused her research on nationalism in Indo-nesian literature as a learning material. Therefore, the research was expected to be the France in conducting these research.

\section{METHOD}

This research is classified as qualitative descriptive research because the analysis uses a qualitative approach. This approach is used because the problems studied involve text (verbal and audiovisual) and the context in society. Qualitative research is a research procedure that produces descriptive data in the form of written or oral words from people or observable behavior. The data collected are in the form of words and images that can be described.

Qualitative research emphasizes processes rather than results. This is because the parts being studied will be much clearer, if observed in the process. Unlike the case with quantitative research that emphasizes results rather than proces. The process in qualitative research is carried out throughout the research from beginning to 
end. The results of the research are sometimes found in the process itself.

The main data sources in qualitative research are words and actions, the rest are additional data (Moleong, 1995). Related to this, the type of research data includes words and actions in the audiovisual text of the "Tanah Surga...Katanya" film. Data collection in this study used observation and documentation techniques. Observation is an intense and careful observation carried out by looking at the object of research. Both of these techniques are equipped with recording technique to obtain data related to the research topic. The documents used in this study were VCD of "Tanah Sorga... Katanya" film. VCDs were obtained via the internet by downloading youtube. Other documents in the form of reviews, and news that discuss the film.

The data collected were analyzed by the interactive analysis techniques of Miles and $\mathrm{Hu}-$ bermen model (in Pawito, 2007:104). The model offers analysis technique consisting of three components, namely data reduction, data display, and drawing/verifying conclusions. The data display of data analysis is an activity to assemble information in order to obtain conclusions. The data display were carried out with a description/narrative through the identification and classification of data. The data display were conducted in descriptive qualitative with inductive methods, namely outlining specific problems to acquire general conclusion. The display of descriptive qualitative data is not only limited to the collection and compilation of data, but include analysis and interpretation of the meaning of the data. The results of the data analysis were presented in a narrative, description of the words and statements completed with examples, quotes, and photographs.

\section{FINDINGS AND DISCUSSION}

\section{Findings}

Before the analysis presented, at the beginning, a summary of the story of the "Tanah Surga...Katanya" film will be presented. This summary contains story plots, such as exposition, introduction conflict, conflict itself, and resolution.

The event began with the arrival of Haris (played by Ence Bagus) from Sarawak Malaysia, a widower who had two children namely Salman (Osa Aji Santoso) and Salina (Tissa Biani Azzahra). During this time, Haris worked in Sarawak and occasionally just returned to his hometown in Kalimantan. His two children were entrusted to his father named Hasyim (Fuad Idris) who was already sick. Haris invited his father to move to Malaysia because his condition was better there. Health facilities are available, it is easy to find work, transportation and smooth communication, and so on. But Haris refused, arguing that Indonesia was the land of heaven and more prosperous. Besides that, because of historical reasons and national patriotism.

Haris claimed to have had a shop there and had even married a Malaysian woman, so that everything would be easy to live in. But Hasyim, a former Dwikora operation fighter as an Indonesian volunteer who was involved in the Indonesia-Malaysia confrontation in the 1960s, then refused his son's wishes. "Why don't you all move the graves of your mother and wife?" said Hasyim angrily. For him Indonesia remained the land of heaven, even though Haris denied it and said that heaven only belonged to Jakarta. Finally, only Salina joined her father. Salman chose to live with his grandfather in West Kalimantan.

Public facilities in the border areas of the two countries are very opposite. Conditions in Kalimantan are worse than Malaysia, there is no electricity, dirt roads, and lighting are still using torches. In Sarawak (Malaysia), the road is paved, there is electricity and lights. At the Kalimantan border, there is no shop that trades, but in Sarawak, there are many shops that provide everything. Even, the currency in the border area use ringgit following the Malaysian currency, the Rupiah does not sell. Salman saw two merchants who used red and white flags as base to hold merchandise and other figures used the red and white flag to close the merchandise.

Educational facilities are also very concerning, the school building is damaged. There is only one teacher named Astuti (Astri Nurdin) who teaches third and fourth grade students. Even, the elementary school had a vacuum time for one year because there was no teacher. There is also no health facility. Fortunately, doctor Anwar (Ringgo Agus Rahman) came who was called the Intel doctor. Doctor Anwar had expressed love to Astuti to give a shampoo gift. This needs to be understood because shampoo is 
difficult to obtain in the village. Both of them showed their sacrifice and love to develop the villagers.

Astuti, a teacher who was stationed in the village, got the reality of an inappropriate school. A room is divided in two with bulkheads being third and fourth grade elementary school. The saddest is not only the buildings with wooden floors broken down, but most of the children don't know the national anthem of Indonesia and how to draw the true red and white flag. In addition, when Anwar was asked to teach children to temporarily replace Ms. Astuti who was traveling, she noticed that the students did not know Indonesia Raya song. The students are more familiar with the song Kolam Susu 'Milk Pool' created and sung by Koes Plus in the 1970s.

Thanks to Ms. Astuti and doctor Anwar's dedication, one day the village received a visit from government officials. Students prepare traditional music, dances, and poems to welcome the officials. When music and dance are sung, a group of officials feel proud while promising to immediately assist local schools and villages. But, finally, the promise that was recorded by the official secretary, suddenly dropped by the order of officials (Dedy Miswar) because he was disappointed with the poem read by Salman. The official group was offended because Salman appeared with satirical poetry. The song Milk Pool is made in the form of play poetry that insults the government. On that day, officials and entourages returned to the city in frustration at having been humiliated by Salman's play poetry.

While being a health worker in the region, doctor Anwar also realized how difficult it was to get access to information, compared to in Sarawak, information and communication was very easy. On one night, at a shop in Malaysia, there was a football match between Indonesia and Malaysia national team that was broadcast live on television. Malaysia won and was greeted with enthusiasm by residents there, including Indonesian, Haris who side with Malaysia.

Haris's excitement did not last long. When the cheers watched football, he was contacted by his son, Salman, on a cellphone which reported that his grandfather had died. At that time, doctor Anwar, Ms. Astuti, and Salman tried to get the grandfather to the city for treatment. But, it was late because of the long journey by boat. In the middle of the river, the boat engine ran out of gas. Doctor Anwar tried to help with makeshift medicine, but the grandfather suddenly passed away.

\section{The Spirit of Nationalism and Nationality}

From the beginning of the story, the nationalism attitude was taught by Hasyim to his grandson, Salman. Hasyim told of himself during the conflict between Indonesia and Malaysia in the 1960s, during the Dwikora operation. As a volunteer who fought in the confrontation, Hasyim embed Indonesian nationalism into his grandson. It seems that this attitude was held firmly by Salman when his father Haris returned from Malaysia persuaded his father and son to move to Malaysia. The two figures, Hasyim and Salman, rejected the persuasion and remained in Kalimantan, showing a nationalist attitude.

The soul of nationalism is often shown by Salman. Episodes of stories that touched the hearts of the Indonesian people when they saw the red and white flag being harassed. Salman insisted on redeeming the red and white flags used by merchandise by a native in the Malaysian region. Other traders at Sarawak (Malaysia) market use red and white cloth as a base for merchandise. He was annoyed to see that the cloth was a heritage flag that should not be used carelessly. Salman exchanged it for the sarong that had just been bought to replace the flag. His business was successful. With pride, the flag was then brought to run to his country accompanied by Indonesian national songs, Tanah Air 'Motherland' created by Ibu Sud.

The first episode of this film led to a dialogue between Hasyim and his grandson, Salman. Nearing the night's sleep because it was lit by a torchlight, Hasyim told himself at the time of the struggle as the following conversation:

Hasyim : When I was at the border, suddenly, Gurka troops appeared who came from England defending Malaysia. I and volunteers fought on the border. Gurka troops ran helter-skelter, sneaking in the bushes, crossing the slope, and returning to the village.

Salman : The Gurkhas, where are they from?

Hasyim : They are from Nepal or India. They have thick mustache and black face. 
The dialogue led the audience that Hasyim was a nation fighter and later in the following episodes remained consistent with his spirit of enthusiasm. When Haris, his son returned from Malaysia and persuaded his father and his son to move to Malaysia, Hasyim flatly refused, as the following conversation:

\begin{tabular}{|c|c|}
\hline Haris & $\begin{array}{l}\text { : Trading in Malaysia is very } \\
\text { fortunate. One year of seling, I } \\
\text { already has a shop. So, I invited } \\
\text { dad and my son to move. }\end{array}$ \\
\hline Hasyim & $\begin{array}{l}\text { : Why don't you move your wife } \\
\text { and mother's graves to Malay- } \\
\text { sia? }\end{array}$ \\
\hline Haris & $\begin{array}{l}\text { : Malaysia is a prosperous coun- } \\
\text { try. }\end{array}$ \\
\hline Hasyim & $\begin{array}{l}\text { Jakarta is also prospered. Tak- } \\
\text { ing care of the country is not as } \\
\text { easy as like turning your palm. }\end{array}$ \\
\hline Haris & $\begin{array}{l}\text { : What has the government giv- } \\
\text { en to you, dad? They never give } \\
\text { anything for those who had } \\
\text { fought in the border area. }\end{array}$ \\
\hline Hacvim & $\begin{array}{l}\text { I love this country, not for the } \\
\text { government, but for my own na- } \\
\text { tion. }\end{array}$ \\
\hline
\end{tabular}

Hearing his son's words, Hasyim was shocked and his emotions peaked. His heartache recurs. Haris didn't dare to continue the conversation. The situation was very panic, the two children then came. Haris only managed to persuade Salima to Malaysia, while Hasyim and Salman remained in West Kalimantan. The farewell deeply touched the audience's heart because it happened in front of the grave of his wife and grandmother behind the house.

\section{The National Identity Deviation}

Educational facilities at the border (West Kalimantan) are very limited. One of the schools that was used as the background story was SD Negeri 18. Students at the school had one year of vacuum because there were no teachers before the arrival of Ms. Astuti. The fourth grade students cannot draw the Indonesian flag. This is known when Ms. Astuti told students to draw the red and white flag. The color is correct, but the color position is wrong. Only students of Salman (Haris' son) draw correctly.

Even more concerning conditions in the world of education at school at the border, the students cannot sing Indonesian Raya song. Dr. Anwar, who had succeeded in replacing Ms. As- tuti, instructed the students to sing Indonesian Raya song. Compactly, the students sing like the following song lyrics.
Bukan lautan hanya kolam susu 'It's not just a sea of milk'
Kail dan jala cukup menghidupimu 'Fishing hooks and nets are enough to support your life'
Tiada badai tiada topan kau temui 'There is no storm and typhoon you meet'
Ikan dan udang menghampiri dirimu 'Fish and shrimp approach you'
Orang bilang tanah kita tanah sorga
'People say our land is heaven'
Tongkat kayu dan batu jadi tanaman
'Wooden stick and stone become plants'

The lyrics of the song were created and popularized by Koes Plus in the era of the 1970s. Given the popularity of the song to the villages in the country, it is not wrong for children to know the song better. This was also acknowledged by Ms. Astuti because she had not had time to teach the song. He has just been teaching for a month and students have not studied for a year because there are no teachers.

State identity abuse is also experienced by doctor Anwar. When he entered the village, he brought medical equipment items. There were no vehicles, then he had assisted by a student (Salman's classmate) to transport the equipment. The fee is 20 thousand Rupiah and offered one sheet of 50 thousand Rupiah by doctor Anwar. The child refused because he was asked for Ring-git Malaysia. After being given Ringgit money by Ms. Astuti, the kid answered, "ini baru duit!" "this is it (the money)!"

People in West Kalimantan area near Sarawak tend to use RM (Malaysian Ringgit) instead of IDR (Indonesia Rupiah) because buying and selling transactions use Ringgit everyday. "It becomes dangerous later, there is no spirit of nationalism," doctor Anwar said in response to the situation. "Who can forbid?" said Ms. Astuti. The dialogue in this episode became a satire and also a slap for the government that the the value of the Rupiah was very weak in the eyes of the border community, especially with foreign country.

Thanks to the dedication of Ms. Astuti and doctor Anwar, the community began to receive education and health services, although it was still very limited. One day, this isolated village received a visit from government officials. 
Through the head of the local hamlet, Ms. Astuti was told to prepare the best welcoming event with the students. A group of officials were welcomed at school by singing Indonesian Raya songs, regional dances and music as well as poetry readings. Seeing the appearance of children very well with songs, dance and music, officials were very impressed. At the end of each appearance, the official responded by telling his staff to immediately send teachers and art tools to the village school.

After Salman's turn, the best student at the elementary school read a poem titled Tanah Surga 'Land of Heaven'. The poems taken from the poems of the Kolam Susu 'Milk Pool' song were delivered with enthusiasm, as below.

\section{TANAH SURGA 'LAND OF HEAVEN'}

bukan lautan hanya kolam susu, katanya 'it is not just sea, but a pool of milk, he said'

tapi kata kakekku hanya orang-orang kaya yang bisa minum susu 'but my grandfather said only rich people could drink milk'

kail dan jala cukup menghidupimu, katanya 'hooks and nets are enough to support your life, he said'

tapi kata kakekku ikan-ikan kita dicuri oleh banyak negara 'but my grandfather said our fish was stolen by many countries'

tiada badai tiada topan kau temui, katanya 'there is no storm and typhoon you meet, he said'

tapi kenapa ayahku tertiup angin ke Malaysia 'but why was my father blown off to Malaysia'

ikan dan udang menghampiri dirimu, katanya 'fish and shrimp approach you, he said'

tapi kata kakek awas ada udang di balik batu 'but grandfather said have an axe to grind'

orang bilang tanah kita tanah surga 'people say our land is heaven'

tongkat kayu dan batu jadi tanaman, katanya 'wooden stick and stone become plants, he said'

tapi kata dokter intel, belum semua rakyatnya sejahtera 'but the intel doctor said, not all of his people were prosperous' banyak pejabat yang menjual kayu dan ba$t u$ 'many officials sell wood and stone'

untuk membangun surganya sendiri 'to build their own paradise'

The poem received a warm welcome with applause. Only a group of officials who were impressed forced themselves to clap their hands offended by the poem. The play poetry of the Kolam Susu song by Koes Plus insinuates officials who are too engrossed in the image that Indonesia is a prosperous and rich country. There is an ocean like a pool of milk. Just hook and fish nets are enough because fish and shrimp are abundant. There are no calamities like hurricane and typhoon. Others say Indonesia is the land of heaven. Whatever is planted will benefitable.

But the reality is not as beautiful as the song. According to Salman, just rich people can drink milk. Ocean rich of fish are stolen by many countries. Thankfully, now, in the era of President Jokowi, the fish thieves' ship are burned and drowned. No hurricane and typhoon is also incorrect, because natural disasters come in turns such as tsunami, volcanic eruption, flood, and landslide. Indeed, not all people are prosperous, many corruption officials have accumulated their own wealth.

The poem spelled out by Salman made the officials disappointed. At that time, the official secretary (who was played by Brajamusti) was told to write off the list of help that had been promised earlier in offense. That day, the group of officials returned to the city with a heart full of wounds because of Salman's poem. The child was innocent and honestly complained about the contents of his heart which were indeed felt by them in the border area.

The last episode which at the same time was very staggering from this film was a football match between Indonesia and Malaysia. This match was broadcast live through watching together at a shop in Sarawak. However, on the other side, Hasyim breathed his last on a difficult journey to the hospital, using a boat. Harassment repeated again because Indonesian native Haris sided with the Malaysian team. The Malaysia tam who won was greeted with cheers, including Haris. However, the excitement meant nothing because he got a call from Salman who said he had died. Haris cried because he realized that he had never paid attention to his father's health. 
But instead, he ran away from the responsibility to move to another country and marry a Malaysian women.

\section{The Fact Representation}

Based on the episodes and events of "Tanah Surga...Katanya" film, then some of the causes of the deviation of state identity and the fading of the nationalism, can be identified: (1) the development and economic growth in the border area, in this case West Kalimantan is far behind Sarawak (Malaysia); (2) educational facilities are very concerning, such as lack of teachers, school buildings, and damaged learning facilities; (3) health facilities are very limited like lack of health workers and health services (hospitals); (4) the road transportation is still a dirt road, using water transportation, while in Sarawak the road is paved; (5) the communication facilities are limited, the signal is limited, while in Sarawak the signal is better; and (6) employment is limited hence the residents looking for work in Sarawak even move to become Malaysian citizen.

The 90-minute film gave a message that it was a great task for the government to immediately improve the situation in the border area. Such areas must receive even greater attention because they are part of Indonesia. There should be no terms like the outermost, remote, and isolated area, but the border areas are the frontier region of Indonesia which is the window to Indonesia. The film tells us that the country could not guarantee the basic needs of the people. In addition, the country also forgets to establish a shared identity of the Indonesian people in the border area. This film reminds us that the progress of the country is uneven, because lagging behind development and economic growth is still unequal. If in the New Order era, the film was likely to get censorship from BSF because it was not in line with the government's ideology at that time.

This film in the narrative discourse study is not excessive because it is in fact supported by the news of the National News Agency Antara, which was reported by several media outlets. It was reported that a number of Indonesian citizens living in the border region chose to migrate and live in neighboring Malaysia. The head of the Sumantipal Village, Lumbis Ogong District, Nunukan Regency, East Kalimantan Province,
Mr. Juni admitted that a number of residents in his village had anododus to Malaysia's Sabah state. "At present, there may be 627 families from their villages working and domiciled in Sabah," said Mr. Juni after hearing with members of the East Kalimantan Provincial People's Regional Representative Council (DPRD) on Thursday, December 4th, 2014 (Bali Post, December 5th, 2014 page 24).

According to the Mr. Juni, welfare is the main reason for citizens to migrate to Sabah. In neighboring country, there are jobs, infrastructure is sufficient, and there is sufficient attention from the local government. "Not because I got the lure of 500 Ringgit per month from the Malaysian government, the reason for our residents being moved more because the condition of our village was very isolated," said Mr. Juni. In fact, he him-self planned to move to Malaysia if his position as village head ended. "As for the situation in my village, if there is no concern from government, someday I will move," added Mr. Juni.

In the hearing, Member of East Kalimantan DPRD, Jhony Laim Impang said that the classic problem of the population living in the border area is the economic inequality factor. Actually, residents on the border are still committed to Republic of Indonesia, but because of the problem of demands for life in the end, they have to move to neighboring country. He said to the central government that there are three important things that must be fulfilled by the government for residents in the border region. First, the construction of road infrastructure is quite adequate. Second, the realization of communication facilities, and thirdly the construction of decent house (Antara in Bali Post, December 5th, 2014 page 24).

As such, there is no reason to mention a film discourse is a fabricated result by a story writer and director. This is the truth of Indonesia in a film set in a border area. Film is a representation of the world of facts into the world of fiction which is much justified by film critics, including supported by the statement of the Head of the Sumantipal Village in East Kalimantan as quoted by Antara news. There has been a massive exodus of Sumantipal residents to work in Malaysia.

The dilemma of life in the Indonesia-Malaysia border area is not only experienced by figures like Hasyim, Haris, and his family, but 
also other figures such as Ms. Astuti and doctor Anwar who were willing to serve without getting adequate facilities as public servants. The last message of Hasyim to his grandson, Salman before he passed away was the mandate of this film to all the Indonesian people that, "despite of any circumstances, do not lose our love for this country."

\section{Discussion}

The findings presented above, it turns out, are caused by very low levels of education in the border area. In the field of basic education (SD), students do not get a proper education. This is related to teacher staff, infrastructure, and educational curriculum that are very inadequate. The number of teachers is very limited, even in a year of learning, students never receive lessons because there are no teachers. Even if there is, the teacher concurrently teaches in other classes. In the field of building facilities, benches, and books are very improper, clearly visible in the visualization of the film. The teacher who taught at the elementary school claimed to have erred that he had not taught Indonesia Raya song to children. As a result, students are more familiar with the song, Kolam Susu, which was popularized by Koes Ploes. The song was so familiar in the environment of the children he knew through a radio.

Through such educational conditions, the meaning obtained is that education is managed improvised, without government involvement. Equitable distribution of education in the country is very far from expectations. Progress in education is only distributed in urban areas. The farther away from the national capital, the more depressing conditions, such as in the border area. Therefore, it is natural for children do not recognize Indonesian identity. The Malaysian currency, Ringgit is lauded, while the Rupiah is ruled out. The attitude of such children is also not to blame because daily economic movements in the border area use the Ringgit currency in buying and selling transactions. Drawing Indonesian flag, also the children cannot afford. In this case, the flag is a symbol of the country. Narrative situations in the film's plot invite concern, as Kracauer said, that the film of a nation reflects the mentality of that nation.
Most of the mentalities that the film presents tend to be that characters feel comfortable in neighboring Malaysia. The film cannot be separated from the facts of the world of reality in the border region of Kalimantan with Malaysia. The tension between the film (fiction) and reality (nonfiction), in the narrative statement, is able to give the meaning that the conflict between the characters and characters reflects the reality that occurs. Therefore, the film is an inspiring story that is expected to inspire the government to immediately improve the bad situation in the border area. There was indeed an effort in that direction like the narration at the end of the film that the central official who visited the village was interested in staging students. At that time, it was promised to be assisted by school equipment and arts. Eventually the promise was revoked because of an official offense after hearing the poem that was delivered by Salman which contained scathing criticism. Back here, the role of government is tested. Officials were unable to accept criticism, even though it was conveyed by elementary school children who were honest and innocent.

Based on the analysis of narrative discourse, it can be said that this an interesting communication medium between producers (entrepreneurs), directors, screenwriters, and viewers (the public). The government (ruler) who has the power must move to overcome the existing imbalance. The affairs between businessmen and authorities allows a reciprocal relationship and synergy to educate the nation's children. This film is a unique media because it is able to give a message, not dictate, let alone patronize the audience. But, it flows through narratives that invite the emotions of the audience, are entertaining, cause sympathy or antipathy.

This film is a medium of struggle that is presented in a subtle, irony, and satirical manner, which is able to tickle because it contains criticism, even if the criticism is to the authorities. They ari unlike the case with criticism made by the masses through demonstrations on the streets that sometimes lead to physical clashes with officers. Through the analysis of discourse, it revealed the reality in the border area, which is now starting to get more serious attention from the government. 


\section{CONCLUSION}

"Tanah Surga...Katanya" film tells about the lack of attention of policy holders in this country towards the border region. Set in a remote area of the West Kalimantan border with Sarawak (Malaysia), the people are still left behind in the fields of economy, education, health, and others. Even the currency used is not the Indonesia Rupiah, but Ringgit Malaysia. Likewise, the flag which is a symbol of the state, is seen as alien and not recognized by children. The fourth grade students of elementary school cannot sing the song of Indonesia Raya. They are more familiar with the song Kolam Susu sung by the legendary group Koes Plus which is often heard by radio.

But the disclosure of such story has become a difficult task for the government in the principle of equity in all fields of development. Do not let up because of the lags that do not get the treatment, residents in the border move to neighboring countries because they want a more

\section{REFERENCES}

Genette, G. (1983). Narrative discourse. Oxford: Blackwell.

Heiders, K. (1991). Indonesia cinema: National culture on screen. Honolulu: University of Hawaii Press.

Heryanto, A. (2012). Budaya populer di Indonesia mencairnya identitas pasca orde baru. Yogyakarta: Jalasutra.

Ismail, T., et al. (2004). Hoison esai Indonesia 2. Jakarta: Majalah Sastra Horison Kerjasama dengan The Ford Foundation.

Ismawati, E. (2018). Nationalism in Indonesian literature as active learning model. International Journal of Active Learning, 3(1), 33-48.

Karkono. (2013). Alih wacana cerita-cerita rakyat Indonesia ke film dan drama. Proceeding Mengurai Tradisi Lisan Merajut Pendidikan Karakter. Tabanan: IKIP Saraswati Tabanan Kerjasama dengan Asosiasi Tradisi Lisan.

Luxemburg, J., et. al. (1989). Pengantar ilmu sastra. Jakarta: Gramedia.

Marwoto. (1995). Komposisi praktis. Yogyakarta: PT Hanindita.

Moleong, J. X. (1985). Penelitian kualitatif. Ban- decent life. The soul of nationalism and nationality played by Hasyim with his grandson, Salman needs to be emulated, even though the situation in his village is very alarming. As a fighter and volunteer, Hasyim once joined in a confrontation against Malaysian forces. The spirit of nationalism is always grew in his family. However, it was less successful because his son Haris moved to become a Malaysian citizen. This is not because of him, but because of the contrasting situation and conditions in Indonesia-Malaysia border.

The film is a very interesting film as a learning media for young generation to add insight into nationalism. Rarely is a film that lifts the spirit of nationalism in a unique way, without war and blood. The film is a form of satire towards both central and regional governments and other components of the nation. It is time for development in the border region to get attention, therefore it is in line with the condition of neighboring country.

dung: Rosdakarya.

Paramadhita, I. (2009). Kuasa dalam sinema: Negara masyarakat dan sinema orde baru. Yogyakarta: Ombak.

Pawito. (2007). Penelitian komunikasi kualitatif. Yogyakarta: LKis.

Piliang, Y. A. (2003). Dunia yang dilipat tamasya melampui batas-batas kebudayaan. Yogyakarta: Jalasutra.

Pujiharto. (2012). Pengantar teori fiksi. Yogyakarta: Ombak.

Ratna, I N. K. (2004). Relevansi teori-teori poststrukturalisme dalam memahami karya sastra: Aspek-aspek kebudayaan kontemprer pada umumnya. Denpasar: Universitas Udayana.

Said, S. (1991). Shadows on the silver screen: A social history of Indonesia film. Jakarta: Lontar Foundation.

Sobur, A. (2006). Semiotika komunikasi. Bandung: Remaja Rosdakarya.

Wellek, R. \& Warren, A. (1956). Theory of literature. New York: A Harvest Book Harcourt, Brace and Company 